\title{
Strategy of Developing Marine Tourism Based on Tri Hita Karana in the Village of Serangan, Denpasar
}

\author{
$1^{\text {st }}$ I K Suarta \\ Lecturers of Tourism Department \\ Bali State Polytechnic \\ Bukit Jimbaran Campus, Bali. Indonesia \\ ketutsuarta@pnb.ac.id
}

\author{
$2^{\text {nd }}$ I Putu Budiarta \\ Lecturers of Tourism Department \\ Bali State Polytechnic \\ Bukit Jimbaran Campus, Bali. Indonesia \\ putubudiarta@pnb.ac.id
}

\author{
$3^{\text {rd }}$ A A Pt Swabawa \\ Lecturers of Tourism Department \\ Bali State Polytechnic \\ Bukit Jimbaran Campus, Bali. Indonesia \\ putuswabawa@pnb.ac.id
}

\begin{abstract}
Serangan is a small island surrounded by white sand beaches, and has a strategic location near Kuta, Sanur and Denpasar City. The right development strategy will be able to provide maximum benefits in order to improve the community's economy and environmental sustainability. This study aims to examine internal and external factors and their development strategies. The data used are primary data collected through observation, interviews, questionnaires, with purphosive sampling method involving stakeholder in Serangan Village and secondary data. The data obtained was analyzed by SWOT. The results of the study shows that there are 8 strengths and 7 weaknesses of internal factors with IFAS score of 3.84. External factors have 8 opportunities and 3 threats with EFAS score 4.04. The strategy developed is to support aggressive strategies by utilizing the power they have to capture opportunities. The recommended strategy: S-O is in the form of formulating marine tourism packages both in fullday tour and halfday tour and conducting promotions with Denpasar Government. S-W: strengthening local potential, providing information widely and utilizing transit guests \& early check out for tracient tours. W-O: Undertake training efforts for the community on the need for seven charm program (saptapesona), special souvenirs, complete infrastructure, strengthen the tourism awareness group (Pokdarwis) \& coastal layout. W-T: Maximizing the role of society organisations(banjar and sekehe) as well as socializing tourism to the community. The recommendations given are the results of tourism contributions that need to be returned to the village to strengthen the THK value in the local area.
\end{abstract}

Keywords—component, formatting, style, styling

\section{INTRODUCTION}

Serangan Village is a small island with an area of $476 \mathrm{Ha}$ and $60 \%$ of its territory is a coastal area. According to Indonesian Law No. 1 Year $2014^{1}$, it is stated that Small Island is an island with an area of 2,000 km2 with the unity of its ecosystem. The livelihood of the Seranganpopulation varies since the construction of the road that connectedthe island with Bali Island. The fishermen who used to fishing, now they are handling tourists. The village has some marine potentialssuch as white sandy beaches, seaweed, clear blue sea that adorns the coast of Serangan Island, coral garden and mangrove forest (Suarta, et al, 2017: 3) ${ }^{2}$

Ideally the development of tourist attraction should be done by combining local potential by involving the local community. As a coastal area, the development of tourism is focused on the potential attraction of marine tourism based on local culture. Demographically $89.7 \%$ of the population are Hindus, so the development concept refers to traditional values of local culture known as Tri Hita Karana (THK). The THK-based tourism is a philosophy, concept, which aims to embody the three balances of harmonious relations, namely the balance between humans and God, humans and humans, and humans and their environment. Purwita mentions Tri Hta Karana consists of the word tri means three, hita means happiness and karana means cause. Thus Tri Hta Karana is defined as three balances which cause happiness (Windia et al, 2005: 2) ${ }^{3}$. According to Ashram, who was quoted from (Suarta, et al, $2013)^{4}$ stated that in order to achieve a harmonious life, there are several concepts that support THK such as 1) The concept of SekalaNiskala (real world and unreal world), 2) Rwabhineda (a two-difference), 3) Tattwamasi (we are the same), 4) luan-teben (sacred-non-sacred), 5) tri semaya (threedimensional mirror of life), 6) desamawacara(village habbits) and desa kala patra (place, time, and condition), 7) catur purusa arta (four goals of life), 8) panca srada (five beliefs) and 9) sad kertih (six efforts to support welfare).

The THK concept is carried out to actualize the sustainability values of local communities. Its basic principle is tri kaya parisuda (the right thinking, the right doing and the right acting), tri guna (three characteristics that influence the human beings). Another concept that strengthens the implementation of THK is tri angga (is an expression of values from the largest space of the universe to the smallest elements in humans and architecture, which is closely related to tri mandala(three regions applied to the holy place in Bali. Utama mandala (the main space where the place of worship which is usually placed on the part of Uranus is a sanctified place that is a mountain or kaja (north), Madya Mandala (medium place) is 
a space where the community conduct activities, namely traditional villages (in village scope) and homes within the family. The last is Nista Mandala connoted by the sea, kelod (north) is a place to dispose of garbage as shown in Figure 1.

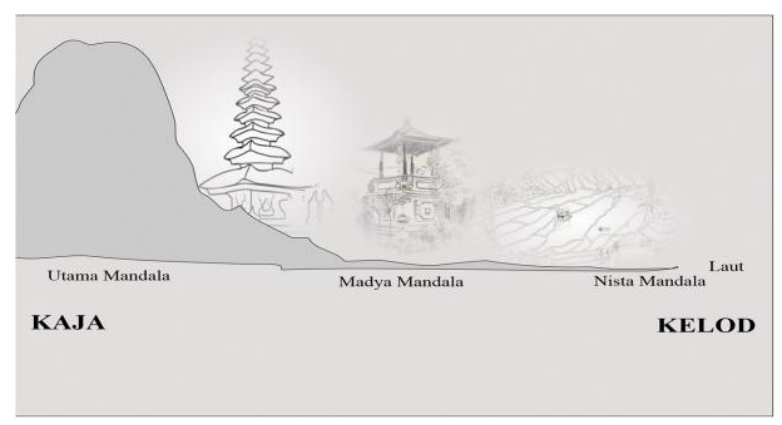

Fig 1: Tri Mandala Concept (Budarma, 2017)

Furthermore Pitana $(2010)^{6}$ argues that THK regulates the values of Balinese life, Windia and Dewi (2007)7 state that THK is formed from the values of life in Bali. Windia and Dewi (2007) ${ }^{7}$ provide general guidelines regarding three THK relationships. Arif $(1999)^{8}$ states that the THK concept is basically a universal concept, which essentially exists and is embraced by other communities, even though they are not Hindus.

In order to get maximum results, it needs to be combined with a global concept known as community-based development (PBM). Internationally, community-based sustainable development consists of three pillars, namely social, economic and environmental pillars. These three pillars are interdependent, but the focus is on the economic pillar. Economic development must be able to bring positive impacts on the environment and people's lives. Economic activities that are integrated with the environment will determine the sustainability of the economic life of a society. Economic activities that are integrated with social culture will achieve social justice. While integration between environment and social culture will determine the carrying capacity of the environment. This three-pillar approach will result in economic development that brings prosperity, fairness and environmental friendliness. Sustainable tourism is a model promoted by the UN World Tourism Organization [WTO], 1998) ${ }^{9}$ adapted from a global approach to sustainable development created by the World Commission on Environment and Development [WCED] $(1987)^{10}$. Sustainable tourism strives to manage resources so that economic, social and aesthetic needs can be met, and on the other hand it can maintain cultural integrity, biodiversity and ecological processes (Lu \& Nepal, 2009) ${ }^{11}$. The application of sustainable tourism principles is a big challenge because both individuals, organizations and tourism policy makers interpret and apply the concept of sustainable tourism differently (Lu \& Nepal, 2009). Tourism must work together to transform tourism activities into a means of economic development, especially in destinations where people will get benefit; environmental development to increase awareness and actions for the preservation of the cultural and natural environment; and social development as an instrument to achieve human welfare both physically, mentally, emotionally and spiritually. The use of local sustainable approaches is accelerated by the 'rediscovery' of knowledge about traditional environment and management of traditional resources in Asia (Hamzah, Ong, \& Pampanga, 2013) ${ }^{12}$. Furthermore France (1997: 23-24) ${ }^{13}$ gives a limit to the development of sustainable tourism, it is expected that the relationship between the three elements of tourism, namely the local community, tourists, and resources can run in a balanced and harmonious manner and maintained its quality.

The harmonization values contained in the THK culture have been shown to significantly influence the orientation ability in the community, state and business so that it affects the market orientation. Lu and Nepal (2009) state that sustainable tourism must be carried out with caution in developing countries, because of cultural differences, norms and politics. This suggestion is supported by Tao and Wall (2009) with the conclusion that sustainable livelihood approaches' of developing countries are more sustainable than sustainable tourism approaches. Sustainable development in Bali is guided by a sustainable local philosophy called tri hitakarana (THK) which consists of Parhyangan, Pawongan and Palemahan with the concept of applying a harmonious balance of human relations with God, humans and humans, and humans with nature. This study looks at Community-based Tourism (CBT) products from global sustainable tourism approaches and local sustainable approach - THK.

TABLE 1: DIFFERENCES AND EQUATIONS BETWEENTHK AND CBT

\begin{tabular}{|c|c|c|}
\hline Values & $T H K$ & CBT \\
\hline The difference & $\begin{array}{l}\text { - Local concepts and } \\
\text { values } \\
\text { - It does not cover } \\
\text { economic aspects. } \\
\text { - More easily applied in } \\
\text { local communities to } \\
\text { collaborate with } \\
\text { global concepts } \\
\text { - There is no standard } \\
\text { measure for the } \\
\text { application of modern } \\
\text { management for the } \\
\text { implementation of } \\
\text { development. }\end{array}$ & $\begin{array}{l}\text { - Global concepts and } \\
\text { values } \\
\text { - It covers economic } \\
\text { aspects } \\
\text { - It is more difficult to } \\
\text { understand to be } \\
\text { applied in local } \\
\text { communities because } \\
\text { global concepts are not } \\
\text { yet fully in line with } \\
\text { local concepts } \\
\text { - There is a definite } \\
\text { standard for modern } \\
\text { management }\end{array}$ \\
\hline \multirow[t]{2}{*}{ The equation } & \multicolumn{2}{|c|}{$\begin{array}{l}\text { Both are concepts that emphasize sustainability with } \\
\text { the principles of community-based tourism } \\
\text { development }\end{array}$} \\
\hline & \multicolumn{2}{|c|}{$\begin{array}{l}\text { Both have Ecological Sustainability principles, Social } \\
\text { and Cultural Sustainability }\end{array}$} \\
\hline
\end{tabular}

This study aims to formulate the development strategy of marine tourism in Serangan Village based on local and global values and determine the recommended tourism products. This study uses primary data collected from tourism stakeholders in the village. The problems in this study are: 1) the development strategy of the marine tourist attraction of Serangan Village, 2) to make some recommended tour packages. 


\section{RESEARCH METHODOLOGY}

Data were collected through interviews, questionnaires, observations, by purposive sampling method (Rai Utama, Mahadewi.2012: 75) ${ }^{14}$ involving some tourism stakeholders in Serangan Village. Data was collected directly from the source through interviews, questionnaires, observations and Focus Group Discussion (FGD), then it was analyzed with descriptivequalitative method.

\section{RESULTS AND DISCUSSION}

\section{A. SWOT analysis}

From the results of internal factor analysis as shown in Table 2 (IFAS). Obtained Accessibility, Attraction, Ancillaries, Amenities, potential, community participation, BUMDES and HR are strengths. While weaknesses are mostly sourced from the public regarding understanding of tourism, comfort, cleanliness, the beauty of the environment, souvenirs and the availability of marine tourism facilities.

\section{TABLE 2 : IFAS}

\begin{tabular}{|c|c|c|c|c|}
\hline No & Internal Factors & Rating & Grade & Score \\
\hline 1 & $\begin{array}{l}\text { It has a strategic location } \\
\text { (Accessibility) }\end{array}$ & 4.733 & 0.084 & 0.399 \\
\hline 2 & $\begin{array}{l}\text { It has natural potencies and } \\
\text { good scenery }\end{array}$ & 4.400 & 0.078 & 0.345 \\
\hline 3 & $\begin{array}{l}\text { It has varied tourism objects } \\
\text { (Attraction) }\end{array}$ & 4.333 & 0.077 & 0.334 \\
\hline 4 & $\begin{array}{l}\text { It is managed by a village } \\
\text { corporate (BUMDES) }\end{array}$ & 4.300 & 0.077 & 0.329 \\
\hline 5 & $\begin{array}{l}\text { Availability of Infrastructure } \\
\text { (Ancillaries) }\end{array}$ & 4.200 & 0.075 & 0.314 \\
\hline 6 & $\begin{array}{l}\text { Local Community } \\
\text { Participation }\end{array}$ & 4.167 & 0.074 & 0.309 \\
\hline 7 & $\begin{array}{l}\text { Adequate facilities } \\
\text { (Amenities) }\end{array}$ & 4.000 & 0.071 & 0.285 \\
\hline 8 & $\begin{array}{l}\text { Availability of Human } \\
\text { Resources (HR) }\end{array}$ & 3.933 & 0.070 & 0.275 \\
\hline 9 & $\begin{array}{l}\text { Awareness of the cleanliness } \\
\text { of the marine environment is } \\
\text { lacking }\end{array}$ & 3.433 & 0.061 & 0.210 \\
\hline 10 & $\begin{array}{l}\text { Changes in beach and sea } \\
\text { functions }\end{array}$ & 3.433 & 0.061 & 0.210 \\
\hline 11 & There is no typical souvenirs & 3.200 & 0.057 & 0.182 \\
\hline 12 & $\begin{array}{l}\text { Local people's knowledge of } \\
\text { tourism is not good. }\end{array}$ & 3.133 & 0.056 & 0.175 \\
\hline 13 & Comfort is still not maximal & 3.000 & 0.053 & 0.160 \\
\hline 14 & $\begin{array}{l}\text { Weak understanding of the } \\
\text { community on ecotourism }\end{array}$ & 3.000 & 0.053 & 0.160 \\
\hline \multirow[t]{2}{*}{15} & $\begin{array}{l}\text { Marine Tourism Support } \\
\text { Facilities }\end{array}$ & 2.900 & 0.052 & 0.150 \\
\hline & Total & 3.744 & 1.000 & 3.838 \\
\hline
\end{tabular}

Source: Research Results (2018)

From the results of external factor analysis, there were 8 opportunities and 3 threats as shown in table 3 (EFAS).
TABLE 3 : EFAS

\begin{tabular}{|c|c|c|c|c|}
\hline No & External Factors & Rating & Grade & Score \\
\hline 1 & $\begin{array}{l}\text { Development of marine } \\
\text { tourism packages and sea } \\
\text { food culinary }\end{array}$ & 4.667 & 0.106 & 0.496 \\
\hline 2 & $\begin{array}{l}\text { Transit tour package(half day } \\
\text { tour)for the delayed flight ( } 12 \\
\text { hours) }\end{array}$ & 4.333 & 0.099 & 0.428 \\
\hline 3 & $\begin{array}{ll}\text { The development } & \text { of } \\
\text { information technology } & \text { in } \\
\text { supporting tourism } & \end{array}$ & 4.300 & 0.098 & 0.421 \\
\hline 4 & $\begin{array}{l}\text { Tour package of art and sea } \\
\text { food culinary }\end{array}$ & 4.267 & 0.097 & 0.415 \\
\hline 5 & $\begin{array}{l}\text { Traveling has become the } \\
\text { lifestyle of the nation in the } \\
\text { world today }\end{array}$ & 4.233 & 0.096 & 0.408 \\
\hline 6 & $\begin{array}{l}\text { Some travel agents have } \\
\text { promotedSerangan Village }\end{array}$ & 4.167 & 0.095 & 0.395 \\
\hline 7 & $\begin{array}{l}\text { The interest of tourists tend } \\
\text { to return to nature }\end{array}$ & 4.033 & 0.092 & 0.371 \\
\hline 8 & $\begin{array}{lll}\text { Government policy } & \text { to } \\
\text { develop Village Tourism } & \text { of } \\
\text { Serangan } & & \\
\end{array}$ & 4.000 & 0.091 & 0.364 \\
\hline 9 & $\begin{array}{l}\text { Tied competition among } \\
\text { marine attractions } \\
\text { inTanjungBenoa,Sanur,Badu } \\
\text { ng and the surrounding areas. }\end{array}$ & 3.467 & 0.079 & 0.274 \\
\hline 10 & $\begin{array}{l}\begin{array}{l}\text { Economic and political } \\
\text { conditions }\end{array} \\
\end{array}$ & 3.233 & 0.074 & 0.238 \\
\hline \multirow[t]{2}{*}{11} & Environmental pollution & 3.200 & 0.073 & 0.233 \\
\hline & Total & 3.991 & 1.000 & 4.044 \\
\hline
\end{tabular}

Source: Research Results (2018)

The Strength (S) of Marine Tourism in Serangan Village

a. It has natural potential and good scenery include: 1) Circled by sloping beaches and clean white sand;2) Quiet seawater in the north as a parking place for medium and small boat, 3) Wavy sea water to the east and south as a watersport location, 4) Flora and fauna (various dazzling fish, colorful coral reefs, mangrove forests with marine life), 5) Beautiful scenery (sunset and sunrise).

b. It has a strategic location such as: 1) Strategic location between Sanur, Kuta and close to the city center; 2) Road to Serangan and its environment is good condition;3) Transportation is available

c. Adequate facilities (Amenities) are: 1) Watersport (Surfing, parasailing, waterski, snorkeling, Diving, flying fish, underwater seawalker, banana boat, jetski boat, donut boat, glass bottom, pier / fast boat), 2) lodging;3 ) restaurants;4) culinary tours, 5), souvenirs and 6) turtle breeding.

d. Availability of infrastructure facilities (Ancillaries) which include: 1) dock, 2) parking area, 3) toilet, 4) health center; 5) road environment is good and 6) good telephone and signal network.

e. Tourist Attraction varies (Attraction) in the form of: 1) water sports, 2) fishing, 3) turtle breeding, 4) crossings to Nusa Penida, Lembongan and Lombok, 5) culinary sea food, 6) educational tours (turtle breeding, cultivation 
coral reefs, seaweed, mangrove forests etc.) and 7) Serangan festival

f. Availability of Human Resources (HR)

g. Participation of Local Communities through some existing institutions such as: Formal Village Institutions, Traditional Village Institutions, village security such as Pecalang and Hansip, Youth organisation, tourism awareness group (Pokdarwis), Lifeguards (coastal safeguards), Trader Groups, Fishermen Groups, Seaweed Farmers Groups, Coral Reef Groups and Crafting Groups

h. Managed by village corporate (BUMDES), which is a village-owned business entity formed to handle village finance, so that its management and supervision can be centralized.

The Weaknesses (W) of Marine Tourism in Serangan Village

a. Awareness of the community to the cleanliness of the marine environment is lacking

b. Changes in beach and sea functions

c. Comfort is still not maximal

d. Weak understanding of the community on ecotourism

e. There are no typical souvenirs

f. Local people's knowledge of tourism is not good.

g. Supportingfacilities for marine tourism are less a. City Government policy to develop village tourism of Serangan

b. Marine tourism packages developed

c. Transit tour package for the delayed flight (12 hours) like a half day tour

d. Art and culinary tour packages

e. Changes in interest of tourists return to nature

f. Some travel agents have promoted Serangan Village

g. Traveing has become the lifestyle of the nation in the world today

h. The development of information technology in supporting tourism

The Treat $(\mathrm{T})$

a. Tied competition among marine attraction inTanjungBenoa,Sanur,Badung and the surrounding areas.

b. Environmental pollution

c. Economic and political conditions

Development Strategy of Marine Tourism in Serangan Village From the results of the IFAS calculation, the average score is 3.83 and EFAS is 4.02, it lies in field 1 (Rangkuti; 2017.20) ${ }^{15}$ which supports aggressive strategies as shown in Table 4.

The Opportunities (0)

TABLE 4: SWOT ANALYSIS OF MARINE TOURISM IN SERANGAN

\begin{tabular}{|c|c|c|}
\hline SWOT Analysis Matrix & $\begin{array}{l}\text { Strength (S) } \\
\text { 1. Natural potential and good scenery } \\
\text { 2. Strategic location (accessibility) } \\
\text { 3. Adequate facilities (Amenities) } \\
\text { 4. Availability of infrastructure Facilities } \\
\text { (Ancillaries) } \\
\text { 5. Attractions are varied } \\
\text { 6. Availability of Human Resources (HR) } \\
\text { 7. Participation of the local community } \\
\text { 8. Managed by village corporate }\end{array}$ & $\begin{array}{l}\text { Weakness (W) } \\
\text { 1. Awareness of poor marine environment } \\
\text { 2. Changes in beach and sea functions } \\
\text { 3. Comfort is still not maximal } \\
\text { 4. Weak understanding of the community to } \\
\text { ecotourism } \\
\text { 5. No typical souvenir of Serangan village } \\
\text { 6. Local people's knowledge of tourism is not good. } \\
\text { 7. Supporting Facilities for Marine Tourism is less }\end{array}$ \\
\hline $\begin{array}{l}\text { Opportunities (0) } \\
\text { a. City Government policy to } \\
\text { develop village tourism of } \\
\text { Serangan } \\
\text { b. Developing marine tourism } \\
\text { packages } \\
\text { c. Transit tour package for the } \\
\text { delayed flight ( } 12 \text { hours) like a } \\
\text { half day tour } \\
\text { d. Art and culinary tour packages } \\
\text { e. Changes in interest of tourists } \\
\text { to return to nature } \\
\text { f. Travel agents have promoted } \\
\text { Serangan village } \\
\text { g. Traveling has become the } \\
\text { lifestyle of the nation in the } \\
\text { world today } \\
\text { h. The development of } \\
\text { information technology in } \\
\text { supporting tourism. }\end{array}$ & $\begin{array}{l}\text { S - O Strategy } \\
\text { 1. Establishing cooperation with Denpasar City } \\
\text { Government }(1,2,3,4-\mathrm{a}) \\
\text { 2. Formulating maritime tourism packages both } \\
\text { in full day tour and half day tour }(1,2,3,4,5-\mathrm{b} \text {, } \\
\mathrm{c}, \mathrm{d}, \mathrm{e}) \\
\text { 3. Conducting promotions with the collaboration } \\
\text { of Denpasar City Government and related } \\
\text { industries ( } 7.8-\mathrm{a}, \mathrm{g}) \\
\text { 4. Maintaining environmental beauty based on } \\
\text { the principle of THK (6.7-f) } \\
\text { 5. Synergizing with the tourism industry for } \\
\text { marketing (8-a, g) }\end{array}$ & $\begin{array}{l}\text { W-O strategy } \\
\text { 1. Increasing public awareness in maintaining the } \\
\text { cleanliness and beauty of the environment }(1,2,3- \\
\text { e) } \\
\text { 2. Strengthening the tourism awareness group } \\
\text { (Pokdarwis) }(6-\mathrm{b}, \mathrm{c}, \mathrm{d}, \mathrm{e}) \\
\text { 3. Arranging the layout of the use of the coast and } \\
\text { the surrounding sea }(2,3-\mathrm{a},) \\
\text { 4. Conducting training efforts for the public on the } \\
\text { need for seven charm to increase tourist visits } \\
\text { (1,3,6-e, } \mathrm{f}) \\
\text { Establising typical souvenirs of Serangan Village } \\
\text { (5-b, c, d, f) } \\
\text { Constructing marine tourism infrastructure }(7-\mathrm{a}, \mathrm{b} \text {, } \\
\text { c) }\end{array}$ \\
\hline $\begin{array}{l}\text { Threat }(\mathrm{T}) \\
\text { a. Tied competition among } \\
\text { marine attractions like Tanjung } \\
\text { Benoa, Sanur, Badung and the }\end{array}$ & $\begin{array}{l}\text { S-T Strategy } \\
\text { 1. Strengthening local potential }(1,3,4,5,6-a) \\
\text { 2. Sharing the information of marine tourism in } \\
\text { Serangan (2-a) }\end{array}$ & $\begin{array}{l}\text { Strategy } \mathrm{W}-\mathrm{T} \\
\text { 1. Maximizing the role of banjar(the smallest } \\
\text { community unit) and sekehe(a group of people) in } \\
\text { the application of awig-awig(regulation) which is }\end{array}$ \\
\hline
\end{tabular}




\begin{tabular}{|c|c|c|}
\hline $\begin{array}{ll} & \text { surrounding areas. } \\
\text { b. } & \text { Environmental pollution } \\
\text { c. } & \text { Economic and political } \\
& \text { conditions }\end{array}$ & $\begin{array}{l}\text { 3. Offering Serangan tour to the transit guests } \\
\text { (transient) and early check out guests (2-c) }\end{array}$ & $\begin{array}{l}\text { the local wisdom }(T H K) \text { of the duties and } \\
\text { responsibilities for sustainability and togetherness } \\
(1,2,3,4-\mathrm{b}) \\
\text { 2. Provide an understanding of tourism, economics } \\
\text { and politics }(6-\mathrm{b}, \mathrm{c})\end{array}$ \\
\hline
\end{tabular}

Source: Research Results (2018)

The recommended strategies for developing marine tourism in Serangan Village are as follows:

\section{S - O Strategy}

a. Establishing cooperation with Denpasar City Government.

b. Formulating marine tourism packages both in full day tour and half day tour.

c. Diversifying tourism products, namely increasing the type and number of tourism facilities by utilizing the potential of the village, especially the potential in the BTID area, canals, and cultural potential. So that it can provide many possible choices of products so that can extend the duration of the visit and or add a variety of product choices in Seranganisland. There are several variations of tourism package products that can be prepared and offered to tourists as presented in table 5.8 below.

d. Doing promotion with the collaboration of Denpasar City Government and related industries

e. Maintaining environmental beauty based on the principle of $T H K$

f. Synergizing with the tourism industry for marketing

\section{S-T Strategy}

a. Strengthening the local potentials:

b. Providing extensive information on marine tourism in Serangan (2-a). Increase cooperation with various travel agents that can help promoting and selling tourism products in order to increase the popularity of Seranganisland.

c. Offering Serangan tour to the transit guests (transient) and early check out guests (2-c)

\section{W-O strategy}

a. Increasing public awareness in maintaining the cleanliness and beauty of the environment. Serangan Village is a newly developed, sometimes the community is not ready to plan tourism development as well as opening the understanding of the community to the environmental hygiene. Therefore, it is necessary to improve environmental management by arranging the natural environment on Seranganisland, especially improving the cleanliness and beauty of the village, especially the northern coastal arrangement of Seranganisland. Besides, it is necessary to organize the field as a public place that can be a place of recreation and attraction for villagers and tourists. So that the natural environment of Serangan Village can provide a cooler, more comfortable, beautiful and enchanting atmosphere.

b. Strengthening the tourism awareness group (Pokdarwis): The concept of community-based tourism development and Tri Hita Karana needs to be drafted, planned by tourism stakeholders in Serangan Village.

c. Developing a spatial plan for the use of the surrounding beaches and sea. Considering the very limited land, it is necessary to develop a zonanizationmasterplan for the placement of watersport parking facilities on the beach, so that beach traffic activities are more orderly and water sports activities are more comfortable and safer.

d. Conducting training for the community for seven charm to increase tourist visits.

e. Producing a typical gift of Serangan: Readiness of a typical local product that makes tourists impressed, happy, so that there have memories when returning home.

f. Completing marine tourism infrastructure: Increasing the capacity, amount and quality of public infrastructure on Serangan island which greatly influences the comfort of tourists who visit and enjoy Serangan coastal tourism, especially during the high season. Because most areas in Serangan are controlled by BTID, it is necessary to collaborate with its area managers in the provision of tourism infrastructure and facilities. Road and parking area and accommodation are very important and should be considered. Because Serangan has limited area so it is mpossible to build a hotel in the Serangan village.

\section{W - T Strategy}

a. Maximizing the role of banjar and sekehe in the application of awig-awig local wisdom (THK) on the duties and responsibilities for sustainability and cleanliness.

b. Providing an understanding of tourism, economics and politics

\section{B. Recommended Tourism Products}

There are several potentials that have been developed in Serangan Village, namely: Beaches with white sand, calm seawater in the north, coral reef parks, seaweed and 
fishermen's sea fish. Its development is still not optimal so it is still possible to be maximized. However, there are 2 potentials that have not been developed at all, namely: mangrove forests in the north and views of the sea with sunset and sunrise. From those potentials, a variety of tour package can be made so that the utilization of potential can be maximized as shown in table 5 .

\section{Table 5 : Some Tour package That May Be Developed in Serangan VILLAGE}

\begin{tabular}{|c|c|c|}
\hline $\begin{array}{ll}\text { Potential } & \text { tourist } \\
\text { attraction } & \\
\end{array}$ & $\begin{array}{ll}\text { Marine } & \text { Tourism } \\
\text { Package } & \\
\end{array}$ & Tour package \\
\hline $\begin{array}{l}\text { 1. white sand } \\
\text { beach }\end{array}$ & $\begin{array}{l}\text { Water Sport, } \\
\text { beach tour } \\
\text { (bathing, enjoying } \\
\text { sunset and } \\
\text { sunrise) }\end{array}$ & \multirow[t]{2}{*}{$\begin{array}{cl}\text { Tourist products with } \\
\text { packages: } \\
\text { 1. } & \text { Fullday tour } \\
\text { 2. } & \text { Halfday tour } \\
\text { 3. } & \text { Trancient tour }\end{array}$} \\
\hline $\begin{array}{ll}\text { 2. } & \text { The } \\
\text { boundary } \\
\text { channel for } \\
\text { residential } \\
\text { areas with }\end{array}$ & $\begin{array}{l}\text { canal tours around } \\
\text { Serangan by } \\
\text { fishing boats. }\end{array}$ & \\
\hline
\end{tabular}

\begin{tabular}{|c|c|c|}
\hline & BTID & \\
\hline $\begin{array}{l}4 . \\
5 .\end{array}$ & $\begin{array}{l}\text { Mangrove } \\
\text { forests } \\
\text { Blue sea } \\
\text { Coral reef } \\
\text { park }\end{array}$ & $\begin{array}{l}\text { Educational } \\
\text { Tourism: Turtle } \\
\text { breeding, seaweed } \\
\text { cultivation and } \\
\text { coral reefs }\end{array}$ \\
\hline $\begin{array}{l}6 . \\
7 .\end{array}$ & $\begin{array}{l}\text { Seaweed } \\
\text { Sea fish } \\
\text { produced by } \\
\text { fishermen }\end{array}$ & $\begin{array}{l}\text { Culinary Tourism } \\
\text { (sea food) }\end{array}$ \\
\hline
\end{tabular}

Source: research results (2018)

Tour packages that might be developed in Serangan Village are Fullday tour packages, halfday tours and transient tours in the form of water sport, beach tours (bathing, sunset and sunrise), village tours utilizing tourist canals and culinary tours.

Based on the recommended strategy and for increasing the number of tourist visits to Serangan Village, there are several tourism products that can be offered to tourists as shown in Table 6 below.

Table 6: Potential, Utilization, Activities and Benefits of Visitor Activities

\begin{tabular}{|c|c|c|c|c|}
\hline $\begin{array}{l}\text { Program } \\
\text { concept }\end{array}$ & Resource & Stake-holders & Visitor activities & Benefits felt by the visitors \\
\hline $\begin{array}{l}\text { Marine and } \\
\text { educational } \\
\text { tourism }\end{array}$ & $\begin{array}{l}\text { North and east } \\
\text { coast }\end{array}$ & $\begin{array}{l}\text { The fishermen community as } \\
\text { planners and implementers of } \\
\text { the activities. BUMDES } \\
\text { (Village corporate), Bendesa } \\
\text { Adat (traditional village chief), } \\
\text { are responsible for the } \\
\text { activities. }\end{array}$ & $\begin{array}{l}\text { 1. Enjoy the beauty of } \\
\text { the beach } \\
\text { 2. Enjoy the water sport } \\
\text { 3. Enjoy the mangrove } \\
\text { forest } \\
\text { 4. Enjoy the coral reef } \\
\text { 5. Enjoy the turtle } \\
\text { conservation } \\
\text { 6. Enjoy fishing }\end{array}$ & $\begin{array}{l}\text { 1. Satisfaction after enjoying the beauty of the } \\
\text { beach, sunset, and sunrise } \\
\text { 2. Satisfaction after enjoying water sport, } \\
\text { mangrove forest, coral reef, and fishing } \\
\text { 3. Increasing the knowledge and experience of } \\
\text { water sports and the nature of the beach } \\
\text { 4. Increasing the knowledge and experience about } \\
\text { turtles }\end{array}$ \\
\hline $\begin{array}{l}\text { Culinary } \\
\text { and } \\
\text { Educationa } \\
1 \text { Tourism }\end{array}$ & $\begin{array}{l}\text { In front of } \\
\text { Sakenan Temple, } \\
\text { the north and east } \\
\text { beaches }\end{array}$ & $\begin{array}{l}\text { The fishermen community as } \\
\text { planners and implementers of } \\
\text { the activities. BUMDES } \\
\text { (Village corporate), Bendesa } \\
\text { Adat (traditional village chief), } \\
\text { are responsible for the } \\
\text { activities. }\end{array}$ & $\begin{array}{l}\text { 1. Enjoy various seafood } \\
\text { dishes } \\
\text { 2. Enjoy the atmosphere } \\
\text { of the beach }\end{array}$ & $\begin{array}{l}\text { 1. Satisfaction after enjoying the beauty of the } \\
\text { beach, sunset and sunrice } \\
\text { 2. Satisfaction after enjoying dishes made from } \\
\text { sea fish, seaweed. } \\
\text { 3. Increasing the knowledge and experience of } \\
\text { culinary seafood and beach }\end{array}$ \\
\hline $\begin{array}{l}\text { Transient } \\
\text { tourism }\end{array}$ & $\begin{array}{l}\text { All marine } \\
\text { potentials of } \\
\text { Serangan Village }\end{array}$ & $\begin{array}{l}\text { The fishermen community as } \\
\text { planners and implementers of } \\
\text { the activities. BUMDES } \\
\text { (Village corporate), Bendesa } \\
\text { Adat (traditional village chief), } \\
\text { are responsible for the activities }\end{array}$ & $\begin{array}{l}\text { 1. Enjoy the beauty of } \\
\text { the beach } \\
\text { 2. Enjoy water sports } \\
\text { 3. Enjoying Mangrove } \\
\text { Forest } \\
\text { 4. Enjoy coral reef } \\
\text { 5. Enjoy fishing } \\
\text { 6. Enjoy various seafood } \\
\text { dishes }\end{array}$ & $\begin{array}{l}\text { 1. Satisfaction after enjoying the beauty of the } \\
\text { beach, sunset and sunrise } \\
\text { 2. Satisfaction after enjoying watersoprt, } \\
\text { mangrove forests, coral reefs, turtles and fishing } \\
\text { 3. Increasing the knowledge and experience of } \\
\text { water sports and natural beaches } \\
\text { 4. Satisfaction after enjoying the cuisine made } \\
\text { from sea fish, and seaweed. } \\
\text { 5. Increasing knowledge and experience of sea } \\
\text { food culinary }\end{array}$ \\
\hline
\end{tabular}

Source: Research Results (2018)

\section{CONCLUSIONS}

Based on the above analysis it can be concluded as follows: 1) Accessibility, Attraction, Ancillaries, Amenities, potentials, community participation, Village corporate (BUMDES), availability of tourism resources and tourism lifestyle, information technology, long transit time, the delayed flight which is almost 12 hours, special sea food culinary tours, the interest of tourists that return to nature and government policies are the strengths and opportunities of
Serangan Village to be an alternative tourist destination in Denpasar, Bali. 2) Readiness of the community to develop village tourism such as understanding of tourism, comfort, cleanliness, beauty, utilization of coastal potential and competition among marine tourism destinations, economics, political conditions, environmental pollution are weaknesses. 3) The development strategy of Serangan Village as one new tourist destinations is as follows: a) Establishing cooperation with Denpasar City Government and synergize with the tourism industries to promote, formulate marine tourism 
packages and increase public awareness in maintaining the natural beauty of the environment, b) Strengthening Pokdarwis (a tourism awareness group), arranges the spatial use of the beach and the surrounding sea, produsing souvenirs which are characteristic of Serangan Village and repairing the marine tourism infrastructure, c) Strengthening local potentials, sharing extensive information of marine tourism in Serangan, Offering and directing the transit guests and early check out for enjoying the tour to Serangan Village and d) Maximizing the role of traditional institutions as a strengthen of local wisdom (THK), socialization of community understanding of tourism, economy and politics. 4) Creating tour package in the form of full tour, half day tour or transient tour that utilizes transit guests and early check out in the form of packages: a) water sports, beach tours (bathing, enjoying sunset or sunrise), b) package around the village using the canal tours with fishing boats, c) Educational tour packages in the form of turtle breeding, seaweed cultivation and coral reefs and d) culinary tour packages.

The recommended suggestion is that it is necessary to develop a THK-based coastal area development model that regulates the mechanism of the local values from the tourism results itself, such as returning a bit of tourism yields to traditional institutions for operational development of local values system to remain steady and sustainable.

\section{REFERENCES}

[1] ------, Law of the Republic of Indonesia Number 1 Year 2014 concerning Amendments to Law Number 27 Year 2007 concerning Management of Coastal Areas and Small Islands.

[2] Suarta, I. K., Swabawa, A. A. P., \& Budiarta, I. P. (2017). Special Interest Marine Tourism Development inSerangan Village Denpasar.
International Journal of Applied Sciences in Tourism and Events, 1 (2), 118 .

[3] Windia, W. 2005. "THK and Sustainable Tourism", in the 2005 THK Awards and Accreditation Handbook, Green Paradise, Denpasar.

[4] News. I K, Elistyawati, Ida Ayu. (2013). Tri Hita Karana (THK) Based Tourism Development in Jasri Tourism Village, Karangasem Regency

[5] Budarma I Ketut, Tourism presentation paper: Analog Tourism Culture System, 2017.

[6] Pitana, I. (2010). Tri hitakarana - The local wisdom of the Balinese in managing development. Trends and issues in global tourism, (p. 139. 150). Berlin: Springer. ISSN 1868-0127, ZDB-ID 24599591

[7] Windia, W., \&Dewi, R. K. (2007). Business analysis based on tri hitakarana. Denpasar: Udayana University.

[8] Arif, S.S. 1999. Applying Philosophy of Trihita Karana - Design and Management of Subak Irrigation System, in A Study of Subak as Indigenous Cultural, Scr-d. and Technological System to Establish a Culturally based Integrated Water Resources Management Vol.III. ed S.Susanto), Fac.of Agric.Technology, Gadjah Mada Univ, Yogyakarta.

[9] World Tourism Organization [WTO]. (1998). Guide for local authorities on developing sustainable tourism. Madrid, Spain: World Tourism Organization.

[10] World Commission of Environment and Development [WCED]. (1987) Report of the World Commission on Environment and Development. Retrieved from http://www.un.org/documents/ga/res/42/ares42-148.htm

[11] Lu, J., \& Nepal, S. K. (2009). Sustainable tourism research: An analysis of papers published in the Journal of Sustainable Tourism. Journal of Sustainable Tourism, 17(1), 5-16. doi:10.108/09669580802582480

[12] Hamzah, A., Ong, D. J., \& Pampanga. D. (2013). ASIAN philosophy of protected areas. Johor, Malaysia: Universiti Teknologi Malaysia.

[13] France. L. 1997. The Earthscan Reader in Sustainable Tourism, UK: Earthscan Publications Ltd.

[14] Rai Utama, I Gusti Bagus. Eka Mahadewi, Ni Made (2012). Metodelogi Penelitian Pariwisata \& Perhotelan, Yogyakarta :Andi Ofset \& Undira.

[15] Rangkuti. (2017). Teknik Membedah Kasus Bisnis, Analisis SWOT, Cara Menghitung Bobot, Rating dan OCAI. Jakarta :Pt Gramedia Pustaka Utama 